\title{
Histology and surface morphology of the olfactory epithelium in the freshwater teleost Clupisoma garua (Hamilton, 1822)
}

\author{
Saroj Kumar Ghosh
}

Received - 07 May 2019/Accepted - 27 August 2019. Published online: 30 September 2019; $\odot$ Inland Fisheries Institute in Olsztyn, Poland Citation: Ghosh S.K. 2019 - Histology and surface morphology of the olfactory epithelium in the freshwater teleost Clupisoma garua (Hamilton, 1822) - Fish. Aquat. Life 27: 122-129.

\begin{abstract}
The anatomical structure of the olfactory organ and the organization of various cells lining the olfactory mucosa of Clupisoma garua (Siluriformes; Schilbeidae) were investigated with light and scanning electron microscopy. The olfactory organ was composed of numerous lamellae of various sizes, radiating outward from both sides of the narrow midline raphe, forming an elongated rosette. Each lamella consisted of the olfactory epithelium and a central lamellar space, the central core. The epithelium covering the surface of the rosette folds was differentiated into zones of sensory and indifferent epithelia. The sensory part of epithelium was characterized by three types of morphologically distinct receptor neurons: ciliated receptor cells, microvillous receptor cells, and rod receptor cells for receiving olfactory sensation from the aquatic environment. The indifferent epithelium comprising a large surface area of the lamella, was covered with compact non-sensory cilia. The non-sensory epithelium contained stratified epithelial cells with microridges, mucin secreting mucous cells, labyrinth cells, and basal cells, which were arranged in a layer at the base of the epithelium. Various cells on the olfactory epithelium were correlated with the functional significance of the fish concerned.
\end{abstract}

Keywords: Clupisoma garua, olfactory mucosa, receptor neurons, chemosensation

\footnotetext{
S.K. Ghosh [ڤ]

Department of Zoology, Bejoy Narayan Mahavidyalaya, Itachuna, Hooghly-712 147, West Bengal, India

e-mail: saroj.fisherylab@gmail.com
}

\section{Introduction}

The olfactory system in fishes is a notable sensory organ because it is essentially a chemoreceptor for detecting and identifying water-soluble compounds to collect information about the surrounding aquatic ecosystem. Smell is one of the most significant senses, and it drives basic patterns of behaviors in most teleosts such as foraging, alarm response, predator avoidance, social communication, reproductive activity, and homing migration (Gayoso et al. 2012). Olfactory discrimination depends mainly on the spatial placement of sensory receptor cells lining the olfactory mucosa. A large number of researchers have studied the various aspects of the olfactory organ of fishes (Sarkar and De 2011, Kuciel et al. 2013, Kim et al. 2014, Paschenko and Kasumyan 2015, Kim and Park 2016, Nikonov et al. 2017, Ghosh 2018, Malick et al. 2018). The teleostean olfactory organ displays numerous species variations especially in gross structure and size depending on the life style of species. Teichmann (1954) reported important information on chemoreception in fishes and ordered fishes into three categories: nose fishes, eye-nose fishes and eye fishes based on their ecological niches. Depending on the arrangement of the lamellae against the central axis, Yamamoto (1982) classified the olfactory rosette of fishes into eight 
morphological types: Type B-single longitudinal; Type C-single transversal; Type D-multiple longitudinal; Type E-fan-shaped; Type F-radiative; Type G-fish bone like; Type H-double sided comb-like with a raphe. Two types of olfactory receptor cells bearing either cilia or microvilli on their apical surface are common in teleosts (Samajdar and Mandal 2016, Ghosh et al. 2017) and a third type, the crypt receptor cell, has been described in a variety of fishes and is considered to be a common feature in bony fish (Hansen and Zeiske 1998). Various kinds of sensory cells can be mediated as diverse functional and structural entities with different sensitivities to external stimuli (Yamamoto 1982).

No work of any consequence has been done on the olfactory organ of schilbid catfishes. This is why the present investigation studied the detailed structure and cellular organization of the olfactory epithelium in Clupisoma garua (Siluriformes; Schilbeidae) using light and scanning electron microscopy, and this paper presents a discussion of the functional importance of the olfactory organ within the mode of life and living of this species.

\section{Materials and methods}

Adult specimens of $C$. garua $(17 \pm 1.17 \mathrm{~cm}$ in total length) were obtained from the Ganga River at Kalyani, Nadia district of West Bengal, India. The fish were anesthetized and euthanized with an overdose of 2-Phenoxyethanol (P1126, Sigma-Aldrich) approved by the Institutional Ethical Committee. The olfactory rosettes were then carefully dissected out from the olfactory chamber on the dorsal side of the head under a Zeiss Stemi 2000-C stereoscopic binocular microscope and immediately processed for respective studies.

\section{Histological preparation}

Olfactory rosettes were fixed in aqueous Bouin's fluid overnight. After fixation, the tissues were washed well in $70 \%$ ethanol, dehydrated properly through graded series of ethanol, cleared in xylene and embedded in paraffin wax (Merck). Tissues were cut at $4 \mu \mathrm{m}$ thickness in transverse planes with a rotary microtome (Weswox MT-1090A). Deparaffinized tissue sections were stained with Romies Azan (RA) and Mallory's Triple (MT) stain (Mallory 1936). The staining slides were examined and photographed under ZEISS Primo Star compound microscope.

\section{Scanning Electron Microscopical (SEM) preparation}

After perfusion in vivo with a $2.5 \%$ glutaraldehyde (Merck) solution in $0.1 \mathrm{M}$ sodium cacodylate buffer ( $\mathrm{pH} 7.4$ ) for $25 \mathrm{~min}$, the intact olfactory rosettes were surgically removed from the gross anatomy. The samples were rinsed in repeatedly in $1 \%$ Tween 40 (Sigma-Aldrich) solution and again fixed in the same fixative for $24 \mathrm{~h}$ at $4^{\circ} \mathrm{C}$. Thereafter, the tissues were washed in the same buffer and post-fixed in $1 \%$ osmium tetroxide (Johnson Matthey) for $2 \mathrm{~h}$ at room temperature. The fixed tissues were washed thoroughly in buffer solution and dehydrated through graded series of acetone followed by isoamyl acetate. Samples were then dried in liquid in a carbon dioxide critical point dryer (Hitachi 8CP2) and mounted on metal stubs. Finally, they were coated with platinum palladium at a thickness of $20 \mathrm{~nm}$ under vacuum using AGAR sputter coater and viewed with a ZEISS EVO 18 scanning electron microscope.

\section{Results}

In C. garua, the olfactory organ was located on the anterior part of snout and consisted of paired nares and a nasal cavity. The nasal cavity was located on the dorso-lateral surface in the anterior cranium with mucosa that rose from the bottom into a succession of folds of the olfactory rosette (Fig. 1A). The olfactory rosette was an elongated structure with a 

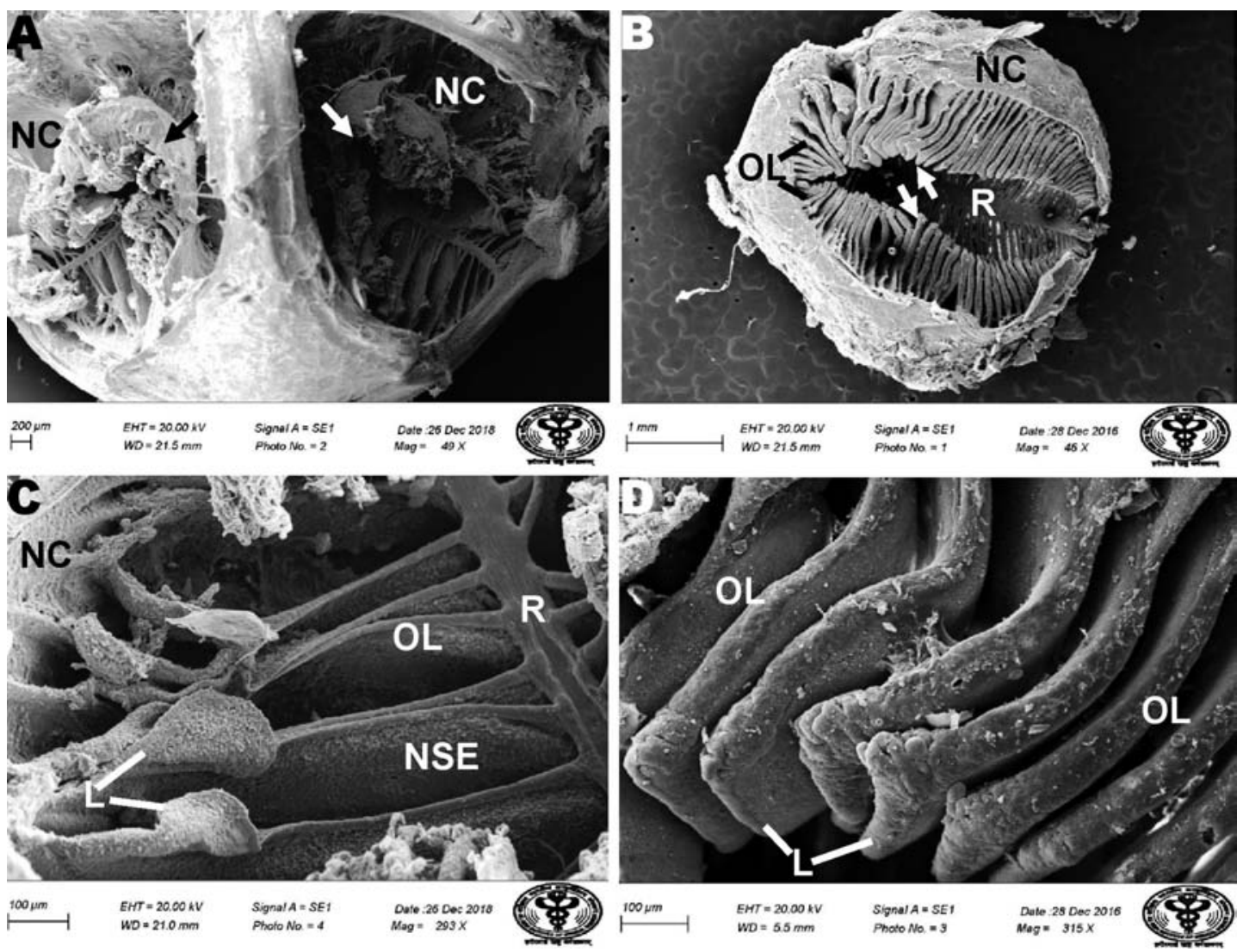

Figure 1. Photomicrographs of the topological view of olfactory epithelium of C. garua by Scanning Electron Microscopy (SEM). (A) Dorsolateral view of olfactory rosettes (arrows) within the nasal cavity (NC). (B) Elongated olfactory rosette in the NC shows the olfactory lamellae (OL) outward from the midline raphe (R). Arrows mark the linguiform processes of the lamellae. (C) OL attached to NC through their ventral margin and with the raphe $(\mathrm{R})$ through their proximal ends. Lamella shows sensory epithelium (SE) in dome-shaped linguiform processes (L) and non-sensory epithelium (NSE). (D) magnified OL shows the linguiform processes.

concave dorsal and convex ventral surface. Each rosette was made up of $40 \pm 2$ finger-like lamellae arranged on both sides of a central axis (Fig. 1B). The anterior and posterior ends of each mucosa were formed of small lamellae, while those in the middle were capacious. The lamellae were arranged parallel to each other in a rostro-caudal pattern. The proximal and distal ends of the lamella adhered to the median raphe and to the wall of the nasal cavity, respectively. A well-developed dome shaped linguiform process arose from the distal free edge of each lamella (Figs. 2C and D). Each lamella was distinguished into sensory and indifferent regions. The sensory epithelium principally occupied the linguiform process and was composed of three types of receptor cells: two were classic with cilia or microvilli and a third had rod-like dendritic terminals. The indifferent epithelium, comprising the greater surface area of the olfactory lamella, was typified by ciliated non-sensory cells, secretory mucous cells, labyrinth cells, and stratified epithelial cells with microridges.

The olfactory lamella contained two layers of epithelium, which was thick and pseudo-stratified with a thin stromal sheet, the central core of which consisted of loosely connective tissue containing a large number of blood vessels and nerve fibers (Figs. 2A and $\mathrm{B})$. A prominent basement membrane separated the olfactory epithelium from the central core (Figs. $2 \mathrm{C}$ and $\mathrm{D})$. The lamellae were entirely wrapped by the epithelium except in the vicinity of the median raphe. The ciliated receptor cells were distinguished by their ovo-elongated, darkly stained nuclei and cylindrical dendrites, which terminated at the epithelial 


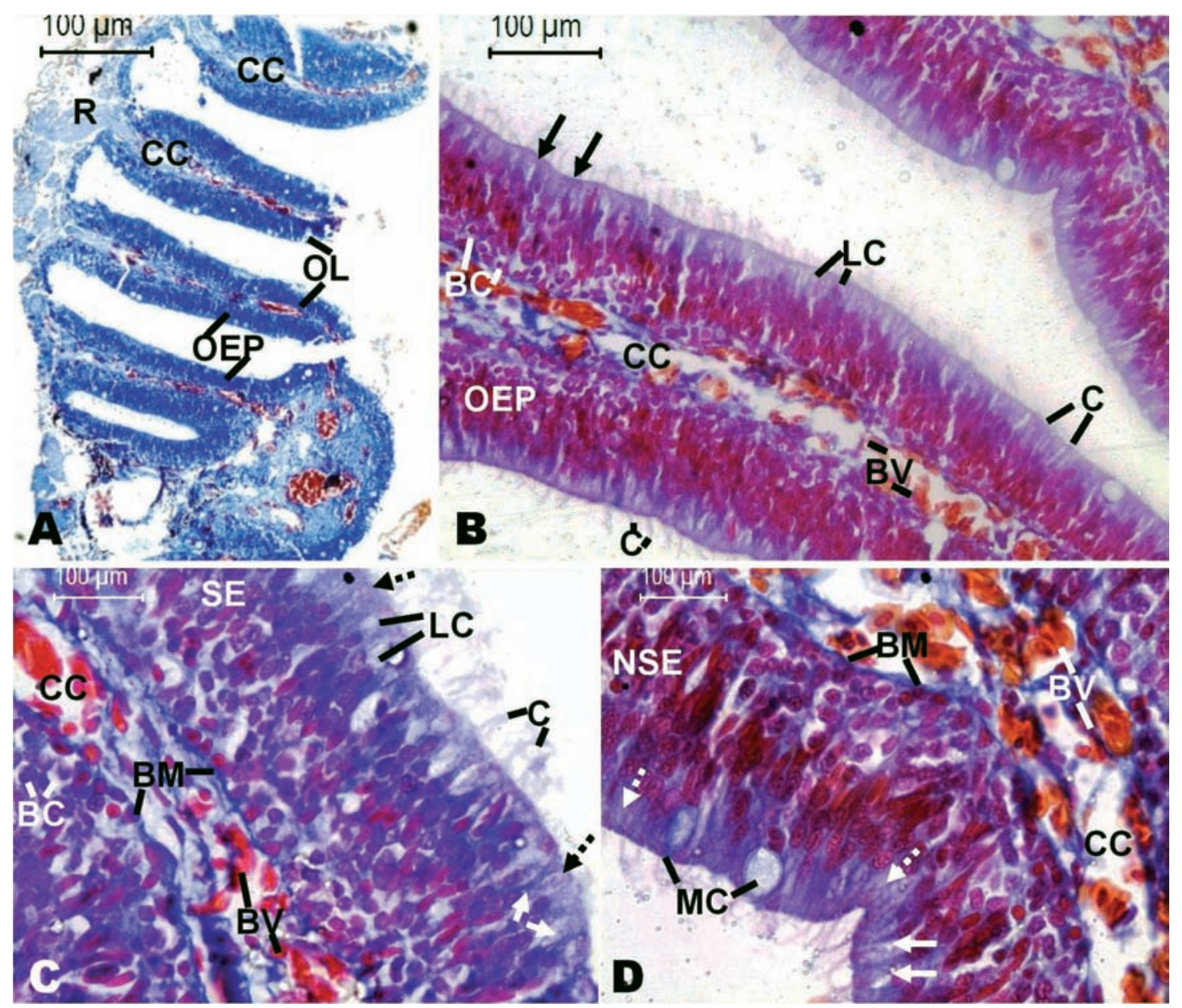

Figure 2. Photomicrographs of the transverse section of the olfactory organ in C. garua stained with Mallory's Triple (MT) and Romies Azan (RA). (A) Section of olfactory lamellae (OL) radiating from the raphe (R) showing the olfactory epithelium (OEP) and the central core (CC) $(\mathrm{MT}) \times 40 \mathrm{X}$. (B) OEP shows the ciliated receptor cells (C), rod receptor cells (arrows), and labyrinth cells (LC). Note the presence of basal cells $(\mathrm{BC})$ close to the basement membrane $(\mathrm{BM})$ that separates the OEP from the CC. BV indicates blood vessels in the CC (RA) $\times$ 400X. (C) Higher magnification of the sensory epithelium (SE) lined with ciliated receptor cells (C), microvillous cells (MV), rod cells (solid arrows), labyrinth cells (LC), and basal cells (BC). Note the presence of BV in the CC, which is distinguished from the OEP by the BM $(\mathrm{MT}) \times 1000 X$. (D) Non-sensory epithelium (NSE) typified by stratified epithelial cells (broken arrows), ciliated non-sensory cells (solid arrows), and mucous cells $(\mathrm{MC})$. The BM separates the OEP from the CC containing BV (RA) $\times 1000 \mathrm{X}$.

surface. The distal portion of the dendrites formed small, knob-like structures studded with cilia (Figs. 2B and C). The microvillous receptor cells were few in number with broad, apical surfaces but without cilia. The cell bodies were more superficial in the epithelium and contained faintly visible round nuclei (Fig. 2C). The rod receptor cells were ovoid, protruded as spike-like structures, and were characterized by highly basophilic nuclei (Figs. $2 \mathrm{~B}$ and C). The ciliated non-sensory cells were tall and columnar in appearance having numerous long cilia at their distal ends. The nucleus was globular and situated in the middle of the cell (Fig. 2D). Mucous cells were broad and oval and were scattered along the border of the olfactory epithelium. These were scanty in the sensory region of the olfactory mucosa, but abundant in the surrounding indifferent epithelium (Fig. 2D). The labyrinth cells were oval in shape with basal nuclei and clear chromatin material distributed evenly (Figs. 2B and C). Stratified epithelial cells were close to the apical part of the epithelium and intermingled with receptor cells. They were characterized by spherical nuclei and less granular cytoplasm (Fig. 2D). Basal cells were oval with conspicuous 


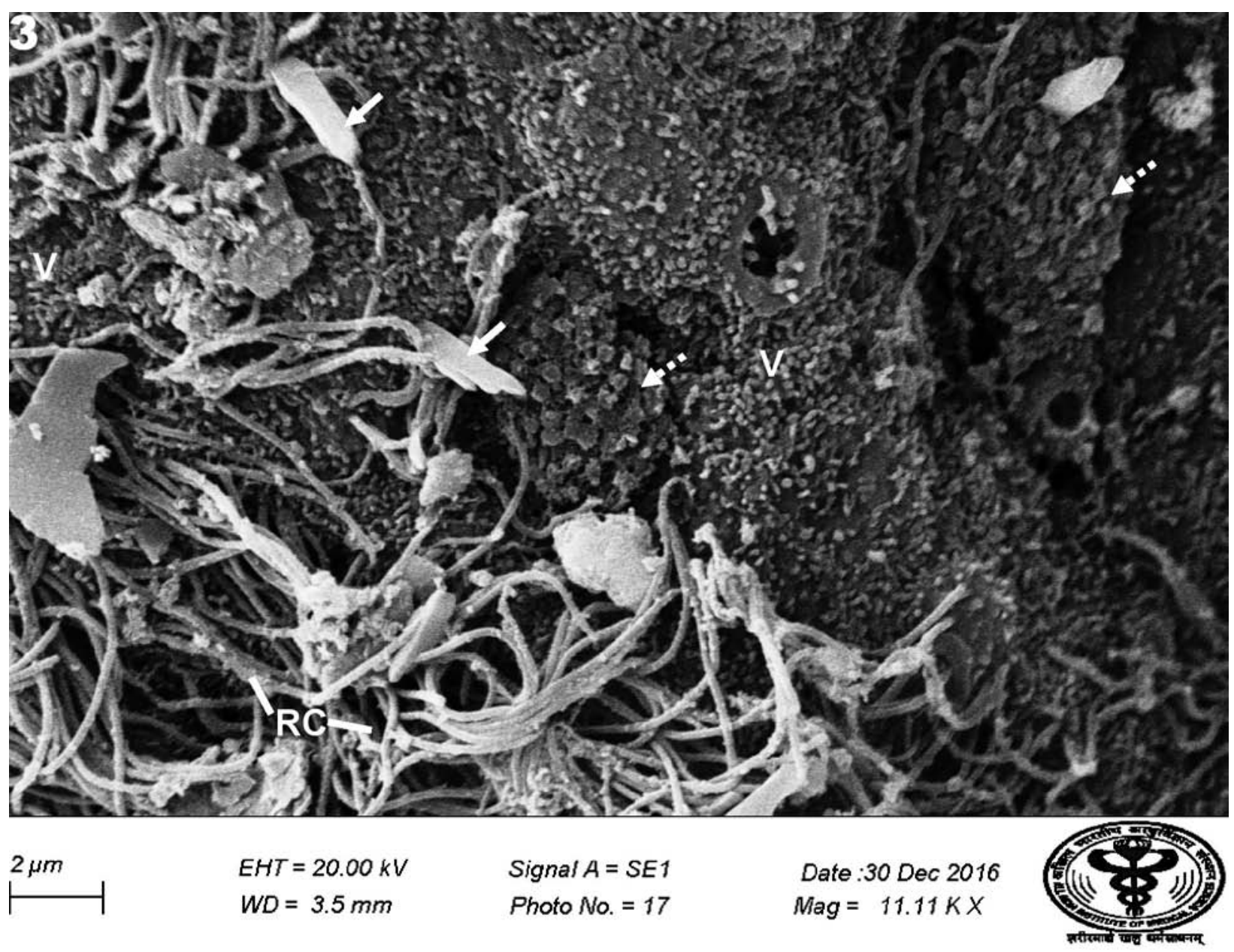

Figure 3. Scanning electron micrograph of the olfactory epithelium of $C$. garua showing the dendrite processes of the ciliated receptor cells (RC) interspersed with microvillous receptor cells (arrow heads). Note the presence of rod cells (solid arrows) and labyrinth cells (broken arrows).

central nuclei in the deeper part of the epithelium adjacent to the central core (Figs. 2B and C). The nucleus was ample in size in comparison to cell magnitude. The basal cells formed a reservoir of superficial cells of the olfactory epithelium.

The surface of the sensory epithelium was embossed with three types of olfactory receptor cells: ciliated, microvillous and rod, which bear a tuft of cilia, numerous microvilli, and lengthen texture, respectively. The sensory islet had a hairy emergence from the compact mass of cilia. Microvillous cells were scattered among ciliated receptor cells, which furnished the sculpture seeming to the free surface (Fig. 3). Rod cells were scanty in number and protruded with a button-like appearance. The labyrinth cells were of a striking texture from the presence of conspicuous infoldings that were dissipated among sensory cells.

The indifferent epithelium had a dense mat of ciliated non-sensory cells and bunches of elevated stratified epithelial cells that consisted of concentric microridges (Fig. 4A). The surface of the non-sensory epithelium exhibited a spongy texture from the thick covering of non-sensory cilia (Fig. 4C). Distinct scattered mucous cell openings with irregular sizes were observed throughout the non-sensory epithelium and the raphe. A considerable number of mucus particles were noted at the opening of the mucous cells and over the stratified epithelial cells (Figs. 4A, B and C). The surface structure of the epithelial cells on the 

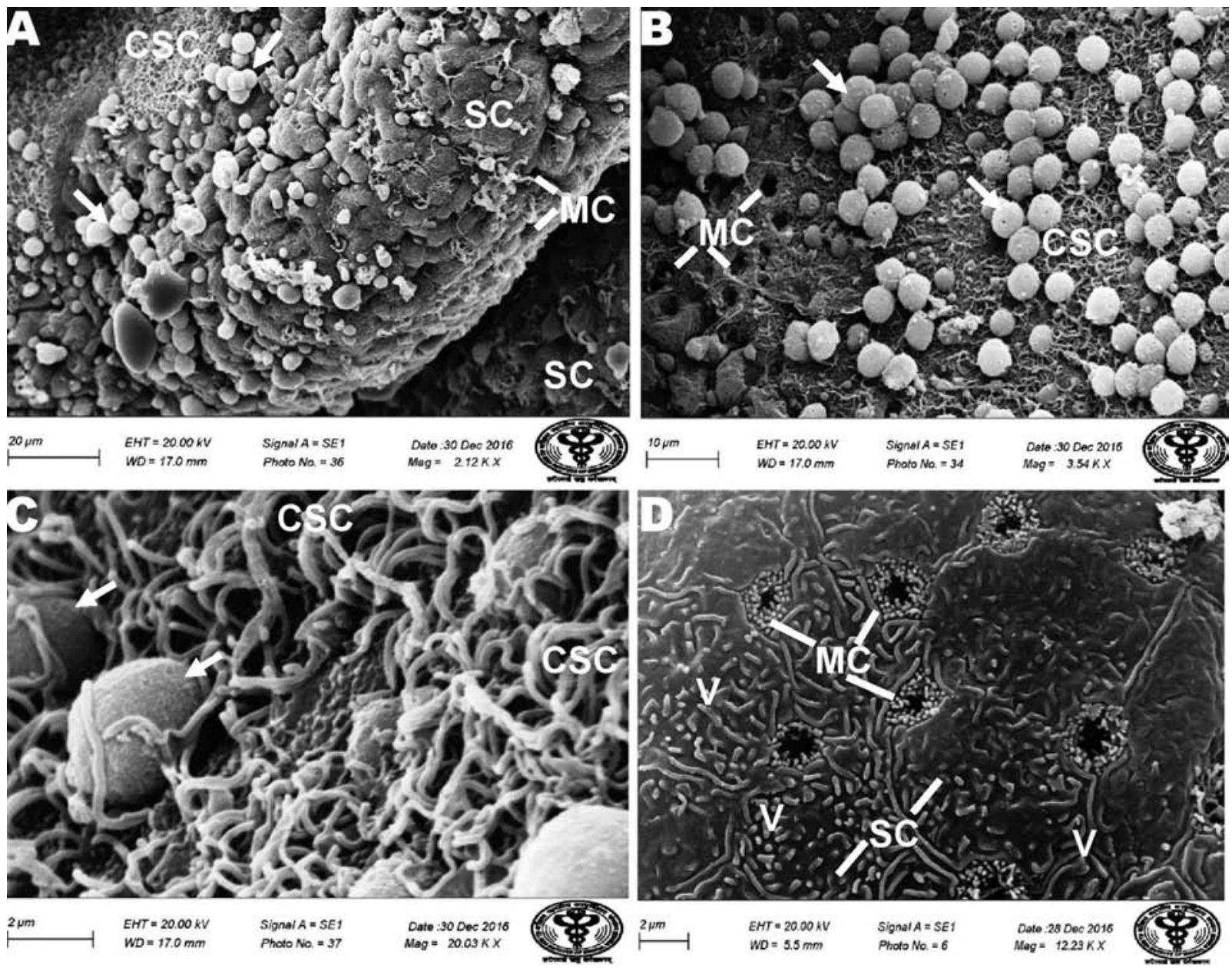

Figure 4. Photomicrographs of the surface view of the olfactory epithelium of C. garua by Scanning Electron Microscopy (SEM) (A) Lamella showing ciliated non-sensory cells (CSC), stratified epithelial cells (SC), mucous cells (MC) with mucin masses (arrows). (B) Considerable numbers of mucus particles (arrows) secreted from mucous cells (MC) and ciliated non-sensory cells throughout the non-sensory epithelium. (C) Higher magnification of the non-sensory epithelium shows a dense mat of ciliated non-sensory cells (CSC) and mucin balls (arrows). (D) Raphe furnishes the opening for mucous cells (MC) among stratified epithelial cells (SC) containing zigzag patterned microridges (arrow heads).

raphe was also composed of zigzag patterned microridges (Fig. 4D).

\section{Discussion}

The olfactory organ detects olfactory cues and pertinent behaviors are performed in any given organism (Mana and Kawamura 2002). In C. garua, the paired elongated olfactory organs with a series of lamellae were located on the anterior aspect of the head, and this species can be classified as Teichmann's (1954) third order, i.e., nose fishes, which implies that olfactory organs are well developed compared to the eyes. The senses of fishes are associated with the crucial, diverse life functions they employ to explore the aquatic environments they inhabit.

In most fishes, the olfactory lamellae are arranged and organized into definite sensory and non-sensory regions depending on ecological habits. The predominantly developed linguiform processes of the olfactory lamellae advances the water current over the olfactory mucosa (Ojha and Kapoor 1972, Ghosh and Chakrabarti 2016). According to architecture of the apical dendrite process on the olfactory mucosa, the receptor cells of $C$. garua can be classified into three 
defined categories: ciliated, microvillous, and rod cells. It is widely know that various types of receptor cells in the sensory epithelium are able to judge chemical changes in the surrounding aquatic ecosystem. Numerous ciliated receptor cells appear on the surface of the sensory epithelium and cilia favor receptor sites. Hara (1986) reports that this receptor cell is directly responsible for detecting and mobilizing various olfactory cues. Functionally, by contact with odoriferous substances, the receptor cell stimulates a signal transduction that is ultimately forwarded to the brain (Hara 1994, Kim and Park 2016). However, receptor cells with rod-shaped dendrite endings were randomly distributed in the epithelium. These receptor cells were of special interest because they formed part of the olfactory transduction mechanism, were stimulated by odor bearing substances, and enabled the fish to detect food. The ciliated receptor cells correspond to type I cells in cypriniformes (Yamamoto and Ueda 1978), and the rod cells are like the type IV cells in gold fish (Ichikawa and Ueda 1977). The microvillous receptor cells might form a different olfactory transduction mechanism for pheromones in the regulation of reproductive activities (Bhute and Baile 2007). The sensory nature of ciliated, microvillous, and rod receptor cells is an established fact and each has a differentiated response to chemical stimuli (Singh 1994).

The enlarged part of the non-sensory epithelium typified by diffuse non-sensory cilia had no sensory function, but it possibly helped in mechanical dissociation. The movement of cilia assists in driving out the mucin mass secreted by the mucous cells (Bandyopadhyay and Datta 1998). The cilia drove streams of incoming water with dissolved chemicals between the olfactory lamellae and over the olfactosensory epithelium. The indifferent epithelium and raphe consisted principally of stratified epithelial cells with microridges that performed the function of supporting tissues disclose to abrasive efficacy (Uehara et al. 1991). The labyrinth cells on the surface of the epithelium might have served as excretory cells for osmoregulation and ion regulation. Shirai and Utida (1970) mention that labyrinth cells might be involved in electrolyte transport because they are structurally similar to the chloride cells found in fish gills. The mucin secreted by mucous cells played important roles since it constitutes an important medium in which the odorants are diffused. Mucus film lubricates the epithelial surface and protects it from the thrust of incoming water during ventilation (Bandyopadhyay and Datta 1998). The basal cells occupied the position in the lower region of the epithelium just above the basement membrane. These cells were differentiated and have been reported to give rise to supporting cells (Ojha and Kapoor 1973). Zeiske et al. (1992) assumed that the basal cells are able to disseminate into receptor cells.

Acknowledgements. The author is grateful to the authority of Sophisticated Analytical Instrumentation Facility, All India Institute of Medical Sciences (AIIMS), New Delhi-110 029 for their help with the scanning electron microscope. The author also extends his thanks to the Department of Higher Education, Science \& Technology and Biotechnology, Government of West Bengal for financial support [Memo Number: 275 (Sanc.)/ST/P/S\&T/1G-37/2017 dt. 27/03/2018].

\section{References}

Bandyopadhyay S.K., Datta N.C. 1998 - Surface ultrastructure of the olfactory rosette of an air-breathing catfish, Heteropneustes fossilis (Bloch) - J. Biosci. 23: 617-622.

Bhute Y.V., Baile V.V. 2007 - Organization of the olfactory system of the Indian Major Carp Labeo rohita (Hamilton): a scanning and transmission electron microscopic study - J. Evol. Biochem. Physiol. 43: 342-349.

Gayoso J.A., Castro A., Anadón R., Manso M.J. 2012 - Crypt cells of the zebrafish Danio rerio mainly project to the dorsomedial glomerular field of the olfactory bulb Chem. Senses 37: 357-369.

Ghosh S.K., Chakrabarti P. 2016 - Histological, topographical and ultrastructural organization of different cells lining the olfactory epithelium of red piranha, Pygocentrus nattereri (Characiformes, Serrasalmidae) - Vestn. Zool. 50: 447-456.

Ghosh S.K., Pan B., Chakrabarti P. 2017 - Structural organization and functional aspects of the olfactory epithelium of red piranha, Pygocentrus nattereri (Kner, 1858) - In: Spare Nature (Eds) S.K. Sinha, S. Majumdar, Damodar Group, Burdwan: 19-35. 
Ghosh S.K. 2018 - Histological Characterization of the Olfactory Organ in Schilbid Catfish, Clupisoma garua (Hamilton, 1822) - Int. J. Aquat. Biol. 6: 281-287.

Hansen A., Zeiske E. 1998 - The peripheral olfactory organ of the zebrafish, Danio rerio: an ultrastructural study Chem. Senses. 23: 39-48.

Hara T.J. 1986 - Role of olfaction in fish behaviour - In: The behaviour of teleost fishes (Ed.) T.J. Pitcher, Johns Hopkins Press, Baltimore: 152-176.

Hara T.J. 1994 - The diversity of chemical stimulation in fish olfaction and gestation - Rev. Fish Biol. Fish. 4: 1-35.

Ichikawa M., Ueda K. 1977 - Fine structure of the olfactory epithelium in the goldfish, Carassius auratus. A study of retrograde degeneration - Cell Tiss. Res. 183: 445-455.

Kim H.T., Lee Y.J., Park J.S., Park J.Y. 2014 - A study on the structure of the peripheral olfactory organ in the Korean mudskipper, Scartelaos gigas (Pisces, Gobiidae) Korean J. Ichthyol. 26: 281-287.

Kim H.T., Park J.Y. 2016 - The anatomy and histoarchitecture of the olfactory organ in Korean flat-headed Goby Lucigobius guttatus (Pisces; Gobiidae) - Appl. Microsc. 46: 51-57.

Kuciel M., Żuwała K., Satapoomin U. 2013 - Comparative morphology (SEM) of the peripheral olfactory organ in the Oxudercinae subfamily (Gobiidae, Perciformes) Zool. Anz. 252: 424-430.

Malick C., Chatterjee S.K., Bhattacharya S., Suresh V.R., Kundu R., Saikia S.K. 2018 -Structural organization of the olfactory organ in an amphihaline migratory fish Hilsa, Tenualosa ilisha - Microsc. Res. Techniq. 81: 1122-1131.

Mallory F.B. 1936 - The aniline blue collagen stain - Stain Technol. 11: 101.

Mana R.R., Kawamura G. 2002 - Olfactory organs of two pelagic teleost fish-Opah (Lampris guttatus) and Dolphin fish (Coryphaena hippurus) - South Pac. Stud. 22: 53-64.

Nikonov A.A., Butler J.M., Field K.E., Caprio J., Maruska K.P. 2017 - Reproductive and metabolic state differences in olfactory responses to amino acids in a mouth brooding African cichlid fish - J. Exp. Biol. 220: 2980-2992.

Ojha P.P., Kapoor A.S. 1972 - Functional anatomy of nose in the teleost Wallago attu Bl. and Schn. - Arch. Biol. 83: 105-116.
Ojha P.P., Kapoor A.S. 1973 - Structure and function of the olfactory apparatus in the freshwater carp, Labeo rohita (Ham. Buch.) - J. Morphol. 140: 77-85.

Pashchenko N.I., Kasumyan A.O. 2015 - Scanning electron microscopy of development of the olfactory organ in ontogeny of Grass carp Ctenopharyngodon idella - J. Ichthyol. 55: 692-712.

Samajdar I., Mandal D. 2016 - Histological organization and ultrastructures of the apical surface of the olfactory epithelium of a carp, Labeo bata (Hamilton) - Int. J. Pure Appl. Zool. 4: 134-141.

Sarkar S.K., De S.K. 2011 - Functional morphoanatomy of olfactory sensory epithelial cells of Pseudapocryptes lanceolatus (Bloch and Schneider) - Int. J. Sci. Nat. 2: 1-6.

Shirai N., Utida S. 1970 - Development and degeneration of the chloride cell during seawater and freshwater adaptation of the Japanese eel Anguilla japonica - Z. Zellforsch. 103: 247-264.

Singh N. 1994 - Scanning electron microscopic study of the olfactory epithelium of four cold water hill stream teleosts from Garhwall hills (India) - J. Biosci. 19: 91-102.

Sola C., Giulianini P.G., Ferrero E.A. 1993 - Ultrastructural characterization of the olfactory organ in glass eels, Anguilla anguilla (Osteichthyes, Anguilliformes) - Ital. J. Zool. 60: 253-261.

Teichmann H. 1954 - Vergleichende Untersuchungen an der Nase der Fishe - Z. Morphol. Oekol. Tiere. 43: 171-212.

Thornhill R.A. 1970 - Cell division in the olfactory epithelium of the lamprey, Lampetra fluviatilis - Z. Zellforsch. 109: 147-157.

Uehara K., Miyoshi M., Miyoshi S. 1991 - Cytoskeleton in microridges of the oral mucosal epithelium in the carp, Cyprinus carpio - Anat. Rec. 230: 164-168.

Yamamoto M. 1982 - Comparative morphology of the peripheral olfactory organ in teleosts - In: Chemoreception in fishes (Ed.) T.J. Hara, Elsevier, Amsterdam: 39-59.

Yamamoto M., Udea K. 1978 - Comparative morphology of fish olfactory epithelium-III cypriniformes - B. Jpn. Soc. Sci. Fish. 44: 1201-1206.

Zeiske E., Theisen B., Breucker H. 1992 - Structure, development and evolutionary aspects of the peripheral olfactory system - In: Fish Chemoreception (Ed.) T.J. Hara, Chapman and Hall, London: 13-39. 